\title{
Public Participation as a Tool for Preserving the Environment
}

\author{
Hen Friman ${ }^{1 *}$, Yafa Sitbon ${ }^{2}$, Ifaa Banner ${ }^{3}$ and Yulia Einav ${ }^{1,4}$ \\ ${ }^{1}$ Faculty of Engineering. HIT - Holon Institute of Technology, Holon, Israel \\ ${ }^{2}$ Dean of Students Office. HIT - Holon Institute of Technology, Holon, Israel \\ ${ }^{3}$ Director of "Israeli Hope". HIT - Holon Institute of Technology, Holon, Israel \\ ${ }^{4}$ Dean of Students, HIT - Holon Institute of Technology, Holon, Israel
}

\begin{abstract}
Environmental Education is the key for creating a clean energy future for not only the nation, but the world. World Energy Consumption relies heavily on coal, oil, and natural gas. Fossil fuels are nonrenewable, that is, they rely on finite resources that will eventually dwindle, becoming too expensive or too environmentally damaging to retrieve. In contrast, renewable energy resources, such as wind and solar energy, are constantly replenished and will never run out. Due to the rising need for professionals and academics with a background and understanding in the Energy field, Holon Institute of Technology (HIT) developed an integral system of environmental education and training and a new program at the Faculty of Electrical Engineering. The Renewable Energy program gives the students technical and practical aspects of energy use (technology and methodology of the study) and energy efficiency. The program also deals with minimizing the environmental impacts of energy use, as well as with energy economy and environmental policy. This article presents a new challenge. Teach environmental issues with language difficulties. Israeli Hebrew speaker students, teach environmental education in Arab school with Arabic speaker pupils'.
\end{abstract}

\section{Introduction}

In Israel, there is a separation between the Jewish education system and the Arab Israeli education system. The decision for this separation has both practical and ideological explanations. There are those who claim that the demographic realities dictate this separation. However it is revealing that the policy since the founding of the state was to strengthen and preserve the Jewish identity amongst the Jewish sector, and a coming to terms with the national identity of the Arab Israeli pupils. The ideological component is the more important of the two; this is evidenced by the fact that even in places where it would be possible to establish a combined education system, like in mixed cities like Ramla. Holon Institute of Technology (HIT) has developed an integral system of environmental education and training. The course is named "Green Ambassadors", and the goal is to educate the next generation environmental education. The course is divided into 6 groups; each group contains 3 to 5 Israeli Hebrew speaker students, whose goal is to provide information on environmental to Arabic school with Arabic speaker pupils'. The teams of five -graders and six -graders from "Alomariya" school in Ramla have been chosen to take part in the project. Concentrate efforts on the improvement of education for sustainable development marked the beginning of a serious reform to cover all types of education and training from preschool to vocational and post university.

\section{Environmental Education in Elementary schools}

Most schools in Israel and throughout the world are appraised by their ability to transfer a large quantity of information to the pupils' over a 12-month period. As the amount of theoretical material is very large and the time teachers have to teach is minuscule, it is nigh impossible to ensure that pupils' understand the material during the lesson. The Arab public school system, legally obliged to provide a level of education equal to that offered to Jewish citizens, is in fact inferior, on average, to the Jewish public school system due, in part, to the unequal budgets and resources allocated by Israel's government. This often creates gaps in knowledge in a range of subjects $[1,2,3]$. Arab students from Israel also find it more difficult than their Jewish peers to meet the demands of an academic system that requires critical discourse, as Arab schools tend to allow less room

* Corresponding author: henf@hit.ac.il 
for expressing opinions and encourage more passive learning $[4,5]$. Therefore, many Arab students are at a disadvantage especially relative to their Jewish counterparts. Many of them lack both the cultural capital $[6,7]$ and the type of academic skills required for coping with Western-influenced Israeli culture, making it difficult for them to match the achievements of their Jewish peers.

Henry Giroux asserts that "while the hidden curriculum cannot be entirely eliminated, its structural properties can be identified and modified" thus enabling the teacher to develop new pedagogical methods [8]. These methods, which Giroux and others identify as critical pedagogy, may partially and temporarily transform the power relations in class and may develop critical and political consciousness among participants, students and teacher. However, critical pedagogy, claims Norman Denzin, "requires citizens and citizen-scholars committed to taking risks, persons willing to act in situations where the outcome cannot be predicted in advance" [9]. bell hooks has accurately acknowledged the reluctance of many teachers "to see the classroom change, to allow for shifts in relations between students" between students and me their teacher [10]. Hooks and Denzin remind me that using methods of critical pedagogy transforms the educational power structure and if I aspire that my class will contain "persons jointly working together to develop new lines of action, new stories, new narratives in a collaborative effort," my authority as the class teacher will be threatened [9]. To create these changes teachers should overcome their fears, work harder, be adventurous, imaginative and spontaneous [10].

\section{Public participation - How?}

According to Ruth Wilson (1994), teaching environmental education in early childhood includes the growth of a sense of curiosity as well as appreciation of the beauty and mystery of the natural world. Education also includes developing problemsolving skills and developing an understanding and appreciation of the world around us. The goal of environmental education is to develop a population that recognizes environmental topics. Studies have shown that most individual positions are formed at a very early stage of life, meaning the teaching environment in early childhood is of great importance [11].

Renewable energy and energy efficiency technologies are the key for creating a clean energy future for not only the nation, but the world. World Energy Consumption relies heavily on coal, oil, and natural gas. Fossil fuels are non-renewable, that is, they rely on finite resources that will eventually dwindle, becoming too expensive or too environmentally damaging to retrieve. In contrast, renewable energy resources, such as wind and solar energy, are constantly replenished and will never run out $[11,12]$.

Due to the rising need for professionals and academics with a background and understanding in the Renewable Energy field, HIT developed a new program at the Faculty of Electrical Engineering. The Renewable Energy program gives the students technical and practical aspects of energy use (technology and methodology of the study) and energy efficiency [13].

As part of this trend the course "Green Ambassadors" was set up. This course integrates work run by the Dean of the Students, the Social Involvement Unit and the "Israeli Hope" in the academia activated at the HIT. Among the goals of the course are making the ecological and environmental issues knowledge accessible to the pupils themselves and the community, bringing to light the importance of keeping the quality of the environment and educating the next generation about basic energy efficiency [14].

\section{The course "Green Ambassadors" for Public participation}

Throughout the course, the HIT students conducted 90 minute lessons each lesson dealing with another important aspect of meaningful environmental issues. The pupils were given examples how to save energy by simple daily actions such as turning off the light when leaving the room and opening the shutters at day time. The lessons passed in a most enjoyable way. At the beginning of each meeting there was a quiz whose purpose was to check the children's initial knowledge of the topic. They got practical experience by the moveable lab which contained a number of demonstrating kits in various subjects: renewable energy, air pollution, waste and recycling, soil contamination and energy efficiency. On every team a group of students had been responsible who studied the topic thoroughly and prepared lesson plans. At the concluding questionnaire was administered which checked the pupils' level of knowledge after the activity. The children turn into more aware in protecting the environment in which they live. Pass on the knowledge and warn the people around from the environmental damage and waste of energy- this serves the purpose of the course-training 
"green ambassadors" from a young age, which will minimize the damage and increase the global consciousness $[15,16]$.

\subsection{Methodology}

"Green Ambassador" course divided into three parts: First part, focused on frontal teaching, delivers knowledge from extensive environmental fields to students. In the second part the students, learnt from the pupils and the school's staff and got to know better the Arab society and its leaders (Fig 1).
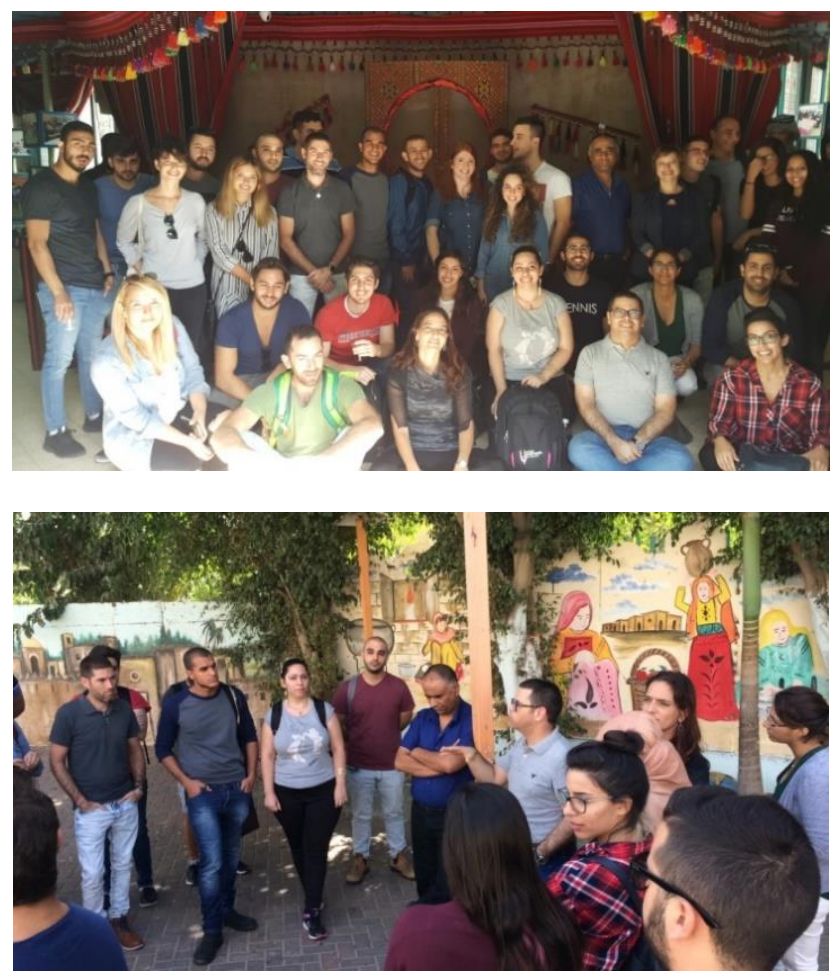

Fig. 1. HIT students visited "Alomariya" school in Ramla and learned from the school's staff about the Arabic society.

The three part of the course shows how the theory becomes practical and concrete. At this stage, students are asked to introduce to the pupils, lesson with language barrier focused on presenting the environmental issues: Energy efficiency (saving), solar energy, energy conversion, air pollution, water pollution, waste, recycling (Fig 2).

The course included "mutual fertilization" the pupils acquired knowledge while the students got familiar with the Arab society in an informal and unprejudiced way (Fig 3).
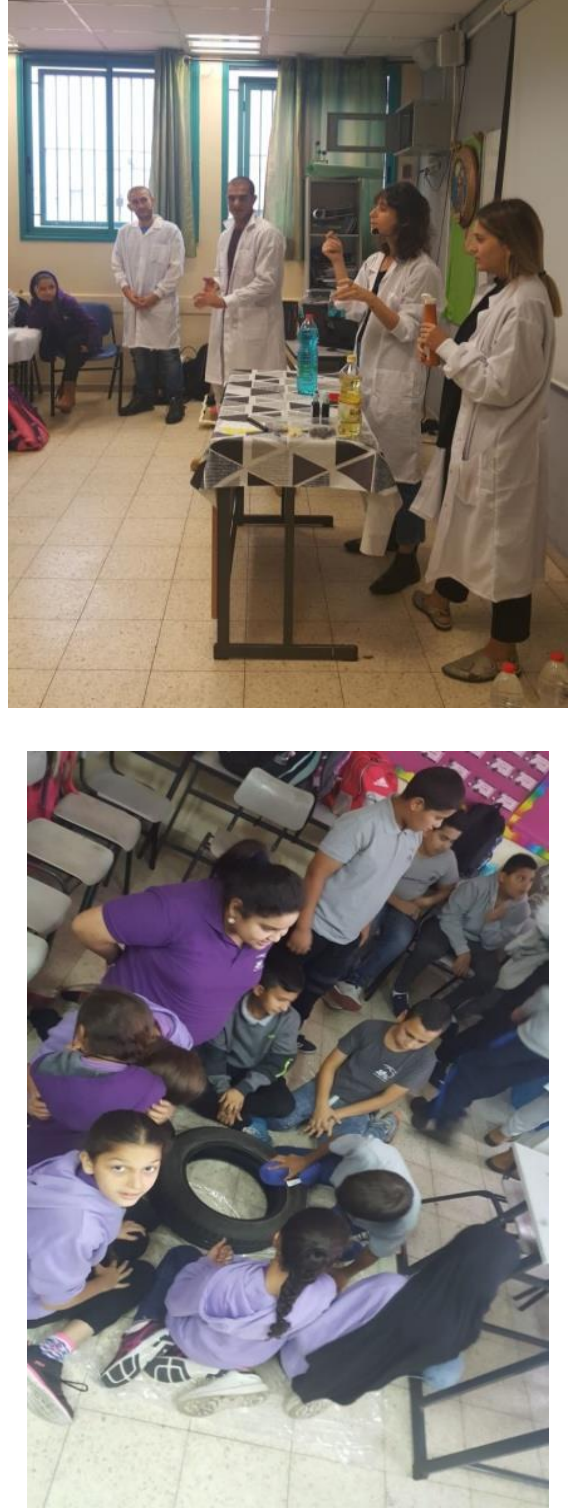

Fig. 2. During meetings held within the school, the HIT students taught the pupils via games and activities what renewable energy means, how to turn waste into a resource, what energy conversion mean etc.

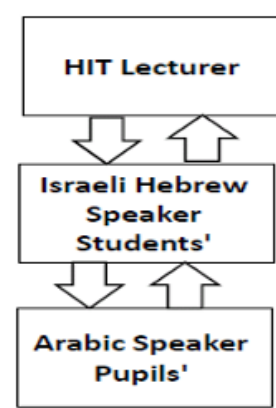

Fig. 3. The course "Green Ambassadors" approach that included mutual fertilization between the students and the pupils, in which the students got familiar with the Arabic society and passed their enviromental knowledge to the pupils. 


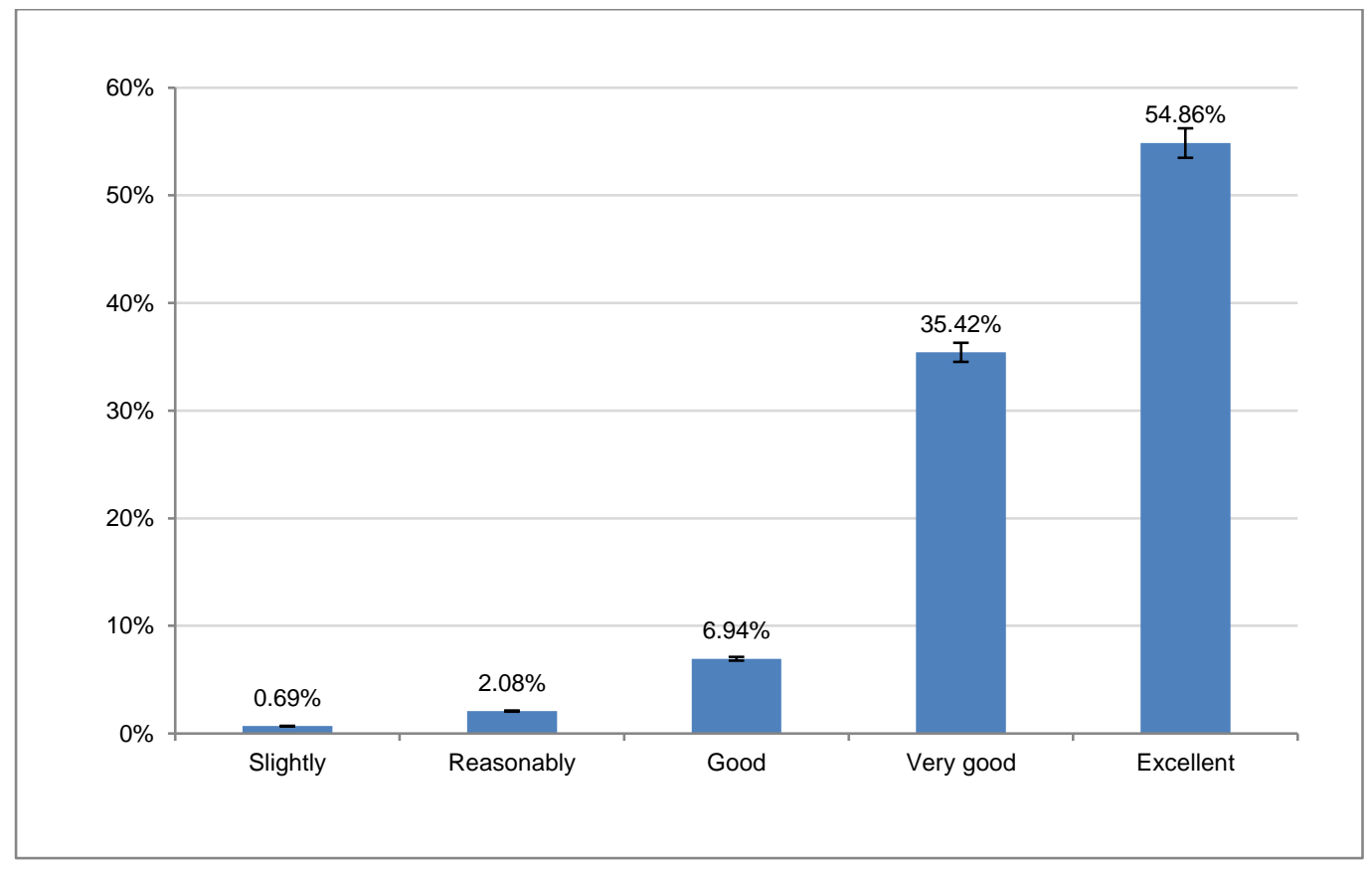

Fig. 4. Pupils general satisfaction

\subsection{Evaluation of teaching efficiency}

The action learning "Green Ambassadors" course is experimental method of teaching, it is important to know the pupils appreciation for it. Each pupil fills an anonymous computerized feedback questionnaire at the end of the course. In this questionnaire they are asked about the overall satisfaction from the new experimental teaching method (Fig.4).

It seems from Fig. 4, that $35 \%$ of the pupils enjoyed the lessons and about $54 \%$ of the pupils enjoyed very much from the lessons. We hope that the pupils were "ambassadors" of environmental awareness among the population. It will encourage public participation for preserving the environment.

\section{Conclusion}

This paper presents a new learning program at the Faculty of Electrical Engineering. The program gives the students technical and practical aspects of energy use and energy efficiency and also deals with minimizing the environmental impacts of energy use, as well as with energy economy and environmental policy. The course "Green Ambassadors" contribute to society and future generations.

\section{Acknowledgments}

We would like to thank the Higher Education Council for budgeting and supporting this course. To the Social Involvement Unit, thanks for their support and for allowing such a course to take place at the
HIT, as well as helping us contribute to society and future generations. Last but not least, we want to thank "Alomaria" School for the opportunity to take a part in the next generation of education for a better and cleaner environment

\section{References}

1. Golan-Agnon, D. (2004). "Inequality in Education". Tel Aviv, Babel. (Hebrew)

2. Jabareen, Y. and Agbaria A. (2011). "Education on Hold: Israeli Government Policy and Civil Society Initiatives to Improve Arab Education in Israe"1. Dirasat: The Arab Center for Law and Policy \& The Arab Minority Rights Clinic, Faculty of Law, University of Haifa.

3. Arar, K. (2012). "Israeli education policy since 1948 and the state of Arab education in Israel". Italian Journal of Sociology of Education, Vol. 4(1), pp. 113141.

4. Barak M. Peleg R. \& Avrahami M. (2000). "Scientific technological education as a focus of the renewal of the Arab-Druze school in Israel" Iyunim B'khinukh (Studies in Education), Vol. 4(2), pp. 51-76 (Hebrew)

5. Al-Haj, M. (2003). "Higher education among the Arabs in Israel: Formal policy between empowerment and control". Higher Education Policy, Vol. 16, pp. 351-368.

6. Bourdieu, P. (1986). "The forms of capital". In J. Richardson (Ed.) Handbook of Theory and Research for the Sociology of Education, pp.241-258.

7. Olneck, M. (2000). "Can multicultural education change what counts as cultural capital?". American Educational Research Journal, Vol. 37(2), pp. 317348.

\footnotetext{
*Corresponding author: henf@hit.ac.il
} 
8. Giroux, H. (1988). "Teachers as Intellectuals: Towards a Critical Pedagogy of Learning". Westport: Bergin \& Garvey.

9. Denzin, N. (2007). "The politics and ethic of performance pedagogy: Toward a pedagogy of hope. In McLaren \& Kincheloe (Eds.), Critical Pedagogy: Where Are We Now?". pp.127-142.

10. Hooks, b. (1994) "Teaching to Transgress: Education as the Practice of Freedom New York, London: Routledge".

11. Simmons, B. McCrea, E., Gay, M., Herrmann, L., Hutchinson, L., Pistillo, M.B., Plevyak, ,L.H,. Rivkin, M., Williams, S., Stenstrup, A., Torquati, J., Weiser, B.G., Wirth, S. (2010). "Early Childhood Environmental Education Programs: Guidelines for Excellence", pp. 2-8.

12. Ariely, D. (2010). The upside of irrationality. pp. 261285
13. Schön, D.A. (1983)."The Reflective Practitioner: How Professionals Think in Action", New York: Basic Books, Inc.

14. Israeli Hope in the Academia (2017) http://www.iataskforce.org/sites/default/files/resource/ resource-1524.pdf

15. Friman, H. (2016). "The Ecological Garden for environmental education through experiential tools". Negev Dead Sea and Arava Studies. Vol. 8, pp. 139146.

16. Fernández-crispin, A., Primo M.E., Lovatón C.T., Olivvera J.P. (2016). "Reflection in Action: A Key to Developing Competences for the Teaching of Science". Athens Journal of Education. pp. 261-263. 